УДК: 75.052

ББК: 85.14

A43

DOI:10.18688/aa166-4-33

Roberta Cerone

\title{
Picturing the Founder. A New Reading of the Stories of St. Benedict in the Lower Church of Sacro Speco at Subiaco
}

About 40 miles east from Rome, stands the extraordinary monument that will be the subject of this paper: the Sacro Speco of Subiaco (Ill. 101). The sanctuary was built on the rocky site where St. Benedict from Nursia took refuge in the early $6^{\text {th }}$ century in search of a suitable place for his hermitage, as reported by his biographer St. Gregory the Great (pope Gregorius I called magnus, 590-604) in the famous Dialogi $i^{1}$. After three years in a cave the saint abandoned the ascetic life preferring a cenobitic model, which led to the foundation of twelve monasteries in Subiaco valley [19, pp. 50-55; 5, pp. 35-47; 29; 32] and to one of the most important Regula of Western monasticism, written later in Monte Cassino abbey [28, col. 200].

Starting from the High Middle Ages, the cave was the object of veneration and pilgrimage, even by the popes of Rome ${ }^{2}$. As a relic it reminded the exemplary life of the saint and his rule, and therefore constituted a warning to the monastic communities of the valley where the abbey of St. Scholastica was taking a leading role [11, pp. 26-27].

Only in the $13^{\text {th }}$ century, from the pontificate of Innocent III (1198-1216), the site became a monumental structure ${ }^{3}$. There was a small church at the lower level of the cave, where the steep path for pilgrims ended. Then there was a first staircase connecting the caves to the socalled "landing of the Bulla" (Ill. 102), named after the fresco with the donation of Innocent III in favour of the monastery. Finally, at the time of Pope Honorius III (1216-1227), a chapel in honour of St. Gregory was built above the first church [36, pp. 78-84].

The works continued throughout the $13^{\text {th }}$ century, and only at the end of it the lower part of the complex acquired its final structure [36, pp. 85-86]. The staircase, first made of rock, was modified and covered with cross vaults. The existing buildings were incorporated into a

There are many studies about this important figure, see at least [6]. St. Benedict escaped from Rome to find some place away from the life of the great city together with his old nurse Cirilla and took refuge first in Affile then in Subiaco valley [28, col. 128].

2 The Liber Pontificalis [18, p. 117] remembers the gift that, following the hypothesis of Egidi [19, p. 59], pope Leone IV (847-855) did to the Speco, but the news is not certainly referred to that site [11, p. 35, note 23]. Nonetheless, in this period the veneration of the place is attested by the fresco with Madonna and Child, painted in the so called "cave of the shepherds", that dates back to the $9^{\text {th }}$ or to the following century [26, p. 287].

About the special relationship between pope Innocent III and Subiaco [11, pp. 61-63] and [16]. 
two-level rectangular block 4 : a lower church adjacent to the cave of Benedict, including the final part of the staircase and the "landing of the Bulla" and a higher structure modified during the $14^{\text {th }}$ century $[23$, pp. $386-287 ; 36$, p. 90]. The latter was probably dedicated to liturgical function and reserved for the exclusive use by the monks who lived in the two-storey building created in the second half of the $13^{\text {th }}$ century on the side of the sanctuary [36, p. 86].

The so-called lower church (Ill. 103), on the other hand, was intended for pilgrims who came from St. Scholastica monastery through the upward path and then the Stories of St. Benedict painted inside were addressed to them. The frescoes were the conclusion of the intensive phases of the construction during the 1200s, representing an extensive hagiographic cycle based on the Life of St. Benedict written by Saint Gregory the Great ${ }^{5}$. The stylistic features of the paintings, in relationship with the most important frescoes of Rome and Assisi in the second half of the $13^{\text {th }}$ century have monopolized the attention of the scholars because of different hands displayed in three bays. This fact suggested the presence of more workshops active simultaneously with Magister Conxolus, the painter who signed the niche with the Madonna and Child: MAGISTER / CONXOLU(S) PI(N)/XIT HOC OP(US) ${ }^{6}$. Less attention, however, was paid to the overall meaning of the cycle in relation to the choice of the episodes and to the function of the images.

The Stories of St. Benedict starts just to the right of the signed niche with a sequence of episodes included in a single lunette: the Miracle of the sieve and the Dressing of Benedict. These are the first miracles of the saint in the valley of Subiaco and the beginning of his hermitical life, according to Gregorius the Great [28, coll. 128-130]. According to this source, the fresco (Ill. 104) depicts on the left the rocky landscape with a few slender trees and red flowers, where the afflicted nurse gives the young Benedict the broken sieve (capisterium). Then the saint is depicted praying toward the Church of St. Peter, and the sieve, now fixed, is represented close to $\mathrm{him}^{7}$. The titulus remembers the location where the miracle happened, i.e. AFIDE, today Affile, a small town near Subiaco. The two stories on the right happened in Subiaco where Benedict took refuge after leaving Affile. First one represents the Dressing of the saint with the monk Romanus who gives Benedict a black robe. Then there is the saint depicted as an adult,who begins his hermitage in the cave. Above it the artist also showed the little monastery where, according to the sources, Romanus lived under the direction of the abbot Adeodatus ${ }^{8}$.

4 On the hypothesis of a simultaneous construction of the upper and lower churches, suggested by the conformation of the two buildings (conformity of the plans and of the outer walls; conformation of the vaults of the lower one etc.) [12].

5 Less attention will be dedicated to the three vaults of the lower church, contemporary to the cycle, showing a sequence of saints related with the history of Subiaco or, in general, with the Benedictine order, see [37, pp. 127-130] and [27, pp. 357-359] for the hypothesis of an earlier realisation of the vaults.

$6 \quad$ For a deep discussion on the artists active in the cycle see at least [15, pp. 120-132; 27, pp. 328, 357-359; 30, p. 437; 37, pp. 131-133]. About the documentary evidence of Conxolus [38].

$7 \quad[28$, col. 128]: "Benedictus autem religiosus et pius puer cum nutricem suam flere conspiceret, ejus dolori compassus, ablatis secum utrisque fracti capisterii partibus, sese cum lacrymis in orationem dedit: qui ab oratione surgens, ita juxta se vas sanum reperit ut in eo inveniri fracturae nulla vestigia potuissent Mox autem nutricem suam blande consolatus, et sanum capisterium reddidit, quod fractum tulerat".

$8 \quad$ [28, col. 128]: "Quo dum fugiens pergeret, monachus quidam Romanus nomine, hunc euntem reperit, quo tenderet requisivit. Cujus cum desiderium cognovisset, et secretum tenuit, et adjutorium impendit, eique sanctae conversationis habitum tradidit, et in quantum licuit, ministravit". 
The next bay appears less coherent in terms of both narrative and style. The upper lunette, in fact, seems to belong to a previous decoration as indicated by the different style, the subject - St. Lawrence between St. Thomas of Canterbury and St. Stephen - and the overlap of the plaster'. Moreover, immediately below one of the last episodes of the life of Benedict is depicted: the Funeral of the saint, with his catafalque among a large group of monks and an angel carrying his soul ${ }^{10}$. The unexpected presence of this episode, the only one which did not happen in Subiaco, probably relates to the request of the monastic patronage who wanted to highlight the importance of the pilgrimage to the cave. Gregorius claims that after the death of Benedict in the Speco many miracles began to happen, like the one described in the final chapter of the Vita Benedicti ${ }^{11}$. Therefore, it doesn't seem a coincidence that the Funeral is placed just in front of the cave, where today an image of Benedict in the cave introduces the Holy Grotto to the pilgrims directed to the Chapel of St. Gregory through a gallery today destroyed [12] (Ill. 105).

The cycle resumes on the third bay with other miracles that happened in Subiaco (Ill. 106). Now Benedict is already leading a community, symbolized by his first pupils Maurus and Placidus, but nonetheless, the frescoes continue to represent him almost always inside the cave, in contrast with the story written by Gregorius and in spite of the iconographic tradition of those episodes $^{12}$. At the top of the eastern wall there is the Rescue of Placidus depicting Benedict ordering Maurus to save his brother who fell into the lake. Below, there is the Miracle of the sickle, where the saint retrieves the tool lost in the lake by a poor Goto. In the first episode Benedict is represented once again in the cave - while Gregorius describes him in his cell - where he finds out that Placidus is in danger, because he fell into the lake, as shown immediately to the right. The saint then called Maurus, depicted in the center of the scene, who already runs to rescue his brother, as suggested by Benedict himself in the titulus FR(ATER) MAURE CURRE VELOCITER. The strange presence of the monastic scapular above the figure of Placidus explains precisely the gregorian passage, in which the monk states: "Ego cum ex aqua traherer, super caput meum melotem abbatis videbam, atque ipsum me ex aquis educere considerabam" [28, col. 146].

The second episode is the only one of the entire cycle where the saint is not depicted sitting inside the cave because, according to the sources, the saint in person grabs the object and

$9 \quad[27$, p. $358 ; 37$, p. 130]. The wall with the triptych of saints is placed in line with the walk of the Scala Santa at the time of Innocent III and therefore it was included in the new structure created in the second half of the $13^{\text {th }}$ century [11].

10 [28, col. 202]: "Cumque per dies singulos languor ingravesceret, sexta die portari se in oratorium a discipulis fecit, ibique exitum suum dominici corporis et sanguinis perceptione munivit, atque inter discipulorum manus imbecillia membra sustentans, erectis in coelum manibus stetit, et ultimum spiritum inter verba orationis efflavit (...). Viderunt namque quia strata palliis atque innumeris corusca lampadibus via recto orientis tramite $a b$ ejus cella in coelum usque tendebatur (...). Quibus ipse ait: Haec est via qua dilectus Domino coelum Benedictus ascendit. Tunc itaque sancti viri obitum sicut praesentes discipuli viderunt, ita absentes ex signo quod eis praedictum fuerat, agnoverunt".

${ }_{11} \quad[28$, col. 202]: "Quadam vero die dum vaga nimium erraret, ad beati viri Benedicti specum devenit, ibique nesciens ingressa mansit. Mane autem facto ita sanato sensu egressa est, ac si eam nunquam insania capitis ulla tenuisset; quae omni vitae suae tempore in eadem quam acceperat salute permansit".

12 See, for instance, the same scenes in the famous manuscript in Biblioteca Apostolica Vaticana, Vat. Lat. 1202, f. 31r, [7, pp. 46-47]. 
takes it back from the lake full of fish ${ }^{13}$. The grotto is still present, but viewed from the outside, as shown by its triangular shape covered by dense vegetation.

In the southern wall of the same bay, thanks to the larger space available, the narrative rhythm slows considerably with a single episode - The miracle of the bread (Ill. 107) - divided into two scenes: on the left the saint is inside the cave with Maurus and Placidus and welcomes the emissary of the bad priest Florentius, who presents him poisoned bread. In the second part of the fresco, Benedict orders the crow to take away the dangerous bread ${ }^{14}$.

The cycle ends inside the cave with two episodes directly linked to the holy place (Ill. 108): the monk Romanus carries the bread to Benedict during his hermitage ${ }^{15}$ and a priest visits the saint after being told of his presence in the grotto, the so called Miracle of the priest at Easter ${ }^{16}$.

The iconographic program thus provides a unitary conception based essentially on a selection of episodes taken from the first part of the life of Benedict spent in Subiaco. The following events, which mostly happened in Monte Cassino, are completely ignored, with the notable exception of the Funeral of the saint whose presence we have already discussed. If the reasons behind this limited selection are obvious inside a monastery in Subiaco, their arrangement is less clear. According to the Vita Benedicti, in fact, the first scenes are those of the first bay, but followed by the episodes painted inside the cave and then by the miracles of the third bay.

The paintings, therefore, should be read in the relation to the original function of this spaces which is totally different from today: the pilgrims climbed the first ramp, so called Holy Steps (scala sancta), then they continued the staircase turning their back to the images of the third bay and, immersed in prayer, could pay only little attention to the scenes on the right wall of the second bay [12]. Moreover, as shown by the frescoes fragments beneath the present staircase ${ }^{17}$, the original steps were on the left of the church, toward the wall where today there is an entrance to the cave. So indeed, the first scenes that the pilgrims could really see were of the lunette with the first miracles.

13 [28, col. 144]: "Vir igitur Domini Benedictus haec audiens accessit ad lacum : tulit de manu Gothi manubrium, [Col.0144D] et misit in lacum: et mox ferrum de profundo rediit, atque in manubrium intravit. Qui statim ferramentum Gotho reddidit, dicens: Ecce labora, et noli contristare".

${ }_{14} \quad$ [28, col. 148]: “Qui ejusdem invidiae tenebris caecatus, ad hoc usque perductus est, ut servo omnipotentis Dei infectum veneno panem quasi pro benedictione transmitteret. Quem vir Dei cum gratiarum actione suscepit, sed eum quae pestis lateret in pane non latuit. Ad horam vero refectionis illius ex vicina silva corvus venire consueverat, et panem de manu ejus accipere".

$15 \quad$ [28, col. 128]: "Vir autem Dei ad eumdem locum perveniens, in arctissimum specum se tradidit, et tribus annis, excepto Romano monacho, hominibus sonum tintinnabuli vir Dei cognosceret quando sibi Romanus panem praeberet, quem exiens acciperet. Sed antiquus hostis unius charitati invidens, et alterius refectioni, cum quadam die submitti panem conspiceret, jactavit lapidem, et tintinnabulum fregit. Romanus tamen modis congruentibus ministrare non desiit".

$16 \quad[28$, col. 130]: “(...) cuidam presbytero longius manenti, qui refectionem sibi in Paschali festivitate paraverat, per visum Dominus apparere dignatus est, dicens: Tu tibi delicias praeparas, et servus meus illo in loco fame cruciatur. Qui protinus surrexit, atque in ipsa solemnitate Paschali cum alimentis quae sibi paraverat, ad locum tetendit, et virum Dei per abrupta montium, per concava vallium, per defossa terrarum quaesivit, eumque latere in specu reperit".

${ }_{17}$ The presence of the fragments has hitherto been ignored by scholars, but it is possible to recognize even two scenes of the same episode: the Temptation of Benedict and Benedict in the brambles [28, col. 132]. For a deep discussion on the identification [12]. 
Then, from "landing of the Bulla" - at that time larger than today - the devotees descended the last stairs to the cave [36, p. 84], where they found the following two episodes of the story painted at the top part of the grotto, perfectly visible from the descent starting point. Back once again to the "landing of the Bulla", they could go down the staircase admiring the other scenes now in perfect chronological order.

Furthermore, despite the fact the Sacro Speco was the symbol of the life of Benedict, at that time the decision to represent a specific selection of his stories was an unusual choice in the Benedictine world. The cycle of Subiaco is, in fact, the oldest and the largest cycle of the life of Benedict that has been preserved after few examples dating from $11^{\text {th }}$ and $12^{\text {th }}$ centuries, like the lost paintings in Montecassino atrium [39, p. 681, note 36], the fragmentary frescoes of San Crisogono in Rome [8] and those in San Magno at Fondi [14] or a capital group in France $^{18}$. To the same period, moreover, date back the series of manuscripts illustrating his life such as the most famous, the Lectionarium Vat. lat. 1202 commissioned by the abbot Desiderius of Montecassino after 1071 [7; 24; 39].

It is curious that his biographical events had not found a large fortune in visual arts, despite Benedict had $a b$ origine a well-established role in the Western Church. However, it does not seem a coincidence that precisely in the late $13^{\text {th }}$ century Subiaco, the cycle of Benedict appeared on such a large scale and with scenes rarely presented previously. The Sacro Speco had just been reformed and completely renewed in its architectonical setting. Moreover, in less than a century it had become, by papal decree, an independent priory from the major monastery of St. Scholastica ${ }^{19}$, so that the small community of monks who lived in close contact with the landmarks of the beginning of the order could retrace more faithfully the teachings of the Rule and set an example for the entire world of the "black monks".

In those years, in fact, the order was beginning to have a hint of the crisis that will invest it heavily in the next century: the rise of the mendicant orders, with their modern spirituality and their presence inside towns, left no chance for the traditional monasticism, which seemed to be incapable of reforming itself from within ${ }^{20}$. In this perspective, the glorification of the founder in the stories of Magister Conxolus seems to suggest, unequivocally, the example to follow, and the cave, which not coincidentally is the prevalent setting of the episodes, is the emblem of the moral virtue of the Speco community, far from the corruption of major monastery and the spiritual decadence prevalent in other abbeys.

Still in parallel with the contemporary history of the mendicant orders, especially the Franciscans, the cycle of Subiaco assumes even other meanings. It can't be any coincidence that in the same years in which the basilica of Assisi was decorated with a new cycle with the Stories of St. Francis ${ }^{21}$ the same happened in Subiaco, while in Benedictine monasteries there had never

\footnotetext{
18 These are the capitals, all dating between the $11^{\text {th }}$ and $12^{\text {th }}$ centuries, in the churches of Sainte-Madeleine in Vézelay, Saint-Benoit-sur-Loire and Saint-Denis $[1 ; 4 ; 14 ; 41 ; 42]$.

19 Under pope Innocent III [16], see in particular the text of the bulla Cum ad monasterium.

20 For a deep discussion on this topic [2; 31; 34, pp. 385-392; 33].

21 The Stories of St. Francis in the upper church of Assisi have been the subject of several excellent studies, but see the most recent $[13 ; 21]$. We should also recall the relationship of Subiaco with the Franciscan world [22], celebrated especially by the frescoes in the chapel of St. Gregory which include a famous image of St. Francis, but for a reading key in a franciscan direction of the entire cycle of that chapel [20, pp. 269-275].
} 
been an established tradition of this kind of decoration. Moreover, in a double-level building that also architecturally seems to allude to the basilica of Assisi $[9 ; 10]$.

To understand the cultural meaning of the Conxolus decoration, we should then consider more general events of the religious world of that time overwhelmed by the problems relating to the mendicant orders and their proliferation [25]. Their rapid growth caused a lively debate within the Church about whether or not to establish new rules of coenobitic life and about the legitimacy of the new orders. These issues were debated during the fourth Lateran Council (1215) and then in the Second Council of Lyons (1274) when the abolition of the congregations created after 1215 were even decreed [3]. The decision led to an intense debate within the friars, involving also Franciscans and Dominicans, about the role and the figure of their founder, whose consequence reached also the Benedictines. If the importance of the traditional monasticism was never questioned, the same historical events are to put it in doubt. The new orders were able to attract the substantial proceeds of alms and considerable human resources, while the black monks began to record a strong decline in vocations.

In general, in the debate about the legitimacy of the rules of life and of the founders, Subiaco strongly reaffirms the value of the Regula Benedicti and exalts the figure of St. Benedict in the place where he had taken the habit and founded his first monasteries, almost in rivalry with the myth of St. Francis that the Franciscans were crystallizing so forcefully in the place of his burial in Assisi.

Title. Picturing the Founder. A New Reading of the Stories of St. Benedict in the Lower Church of Sacro Speco at Subiaco.

Author. Roberta Cerone - Ph. D., postdoctoral researcher. Sapienza University of Rome, Piazzale Aldo Moro 5, 00185 Roma, Italy. roberta.cerone@uniromal.it

Abstract. The frescoes in the lower church of the Sacro Speco at Subiaco closed the complex architectural history which during the $13^{\text {th }}$ century, from the time of Pope Innocent III (1198-1216), saw the growth of the sanctuary created around the cave where St. Benedict of Norcia retired in the early $6^{\text {th }}$ century.

The cycle with stories of the saint, signed by Magister Conxolus, has so far been considered by the critics only for its stylistic and formal characters in connection with paintings in Rome and Assisi during the second half of the $13^{\text {th }}$ century. Starting from these acquisitions, the paper will analyse the selection and the display of the stories - one of the first cycle about the life of Benedict on such a large scale in the Middle ages, — their iconography and their reading direction in relation to the Holy stairs leading to the cave and in the broader context of the debate on new religious orders after the Council of Lyons (1274).

From this perspective, the parallel with the friars and, in particular, with the Franciscans who, just few years before, had glorified their founder in the famous basilica of Assisi, seems once again significant. The similarities with the pictorial cycle of the upper church of San Francesco, in fact, seem to go beyond the stylistic point of contact already identified by the critics to include broader issues. The foundation of two churches in Subiaco and the decoration of the lower one with the celebration of the founder at the time shortly after the frescoes in Assisi, cannot fail to take account of comparison - and perhaps of antagonism - that existed between two types of common life entirely different: the traditional monasticism and the new orders.

Keywords: St. Benedict of Nursia; Subiaco; pilgrimage; Gregorius Magnus; iconography; Benedictine order; Assisi; Mendicant orders; Council of Lyon.

Название статьи. Изображение основателя. Новое прочтение истории святого Бенедикта в нижней церкви Сакро Спеко в Субиако.

Сведения об авторе. Чероне Роберта - Ph. D., исследователь. Римский университет Сапиенца, площадь Альдо Моро, 5, Рим, Италия, 00185. robertacerone@yahoo.it.

Аннотация. Фрески нижнего храма Сакро Спеко в Субиако - завершающий этап сложной архитектурной истории святилища, которое возникло вокруг пещеры св. Бенедикта Нурсийского, подви- 
завшегося здесь в начале VI в., и разрасталось со времен папы Иннокентия III (1198-1216) на протяжении XIII столетия.

Житийный цикл святого, подписанный Magister Conxolus, до сих пор рассматривался учеными только лишь в отношении стилистических и формальных связей с живописью Рима и Ассизи 1290 $\mathrm{x}$ гг. С опорой на существующую историографическую традицию в данной статье предложен анализ выбора и интерпретации сюжетов в одном из первых столь пространных циклов о св. Бенедикте к началу Высокого Средневековья, их иконографии и последовательности расположения относительно Святой лестницы, ведущей в пещеру, а также в широком контексте споров о новых религиозных орденах, начавшихся после Лионского собора (1274).

С этой точки зрения представляется необходимым указать на параллели с другими монашескими орденами, в особенности с францисканским, который всего несколькими годами ранее возвеличил своего основателя в знаменитой базилике в Ассизи. Причем сходство с изобразительным циклом верхней церкви Сан Франческо простирается дальше уже отмеченных критиками стилистических перекличек. Устройство в Субиако вскоре после создания фресок в Ассизи также двух церквей и украшение нижней церкви во славу основателя не оставляет сомнения в соревновательности, а возможно, и антагонизме, которые существовали между приверженцами двух способов общинножития - традиционного монастырского и практиковавшегося новыми орденами.

Ключевые слова: св. Бенедикт Нурсийский; Субиако; паломничество; Григорий Великий; иконография; бенедиктинцы; Ассизи; нищенствующие ордена; Лионский собор.

\section{References}

1. Ambrose K. The Nave Sculpture of Vézelay: the Art of Monastic Viewing, Toronto, Pontifical Institute of Medieval Studies Publ., 2006, 148 p.

2. Andenna G. Le grandi abbazie dell'Italia settentrionale. Il monachesimo italiano nel secolo della grande crisi. Atti del V Convegno di studi storici sull'Italia benedettina Abbazia di Monte Oliveto Maggiore (Siena), 2-5 settembre 1998. Cesena, Centro storico benedettino italiano Publ., 2004, pp. 223-263 (in Italian).

3. Andrews F. Il secondo Concilio di Lione (1274), gli Agostiniani e gli ordini soppressi. Analecta Augustiniana, 2007, no. 70, pp. 161-185 (in Italian).

4. Blum P. Z. The Saint Benedict Cycle on the Capitals of the Crypt at Saint-Denis. Gesta, 1981, no. 21, pp. 73-87.

5. Branciani L. (ed.) Mirzio da Treviri C. Chronicon sublacense (1628-1630). Subiaco, Tipografia Editrice Santa Scolastica Publ., 2014 (in Italian).

6. Brenk B. Ad vocem Benedetto, Iconografia. Enciclopedia dell'arte medievale, vol. 2. Roma, Treccani Publ., 1992, pp. 361-365 (in Italian).

7. Brenk B. Das Lektionar des Desiderius von Montecassino cod. Vat. Lat. 1202. Ein Meisterwerk italienischer Buchmalerei des 11. jahrhunderts. Zürich, Belser Publ., 1987. 311 p. (in German).

8. Brenk B. Die Benediktszenen in S. Crisogono und Montecassino. Arte medievale, 1984, no. 2, pp. 57-66 (in German).

9. Cadei A. Studi sulla basilica di S. Francesco ad Assisi: architettura (prima parte). Arte medievale, s. II, 1988, no. 2, 1, pp. 79-103 (in Italian).

10. Cadei A. Studi sulla basilica di S. Francesco ad Assisi: architettura (seconda parte). Arte medievale, s. II, 1989, no. 3, 1, pp. 117-136 (in Italian).

11. Cerone R. La regola e il monastero. Arte e architettura in Santa Scolastica a Subiaco (secc. VI-XV). Roma, Campisano editore Publ., 2015. 210 p. (in Italian).

12. Cerone R. Limen Paradisi. Il Sacro Speco a Subiaco: la vicenda artistica alla fine del Medioevo. Roma, Campisano editore Publ. (in press).

13. Cooper D. The Making of Assisi: the Pope, the Franciscans and the Painting of the Basilica. New Haven, Yale University Press Publ., 2013. 296 p.

14. Coppola B. Gli affreschi di S. Magno a Fondi. Bollettino della Unione Storia e Arte, s. III, 2013, pp. 149158 (in Italian).

15. Cristiani Testi M. L. Gli affreschi del Sacro Speco. I Monasteri benedettini di Subiaco. Cinisello Balsamo, Pizzi Publ., 1982, pp. 95-202 (in Italian).

16. De Prosperis A. Innocenzo III e i monasteri di Subiaco. Latium, 2008, no. 25, pp. 3-30 (in Italian). 
17. Dubler E. Das Bild des heiligen Benedikt bis zum Ausgang des Mittelalters. St. Ottilien, Eos-Verl. Publ., 1953,187 p. (in German).

18. Duchesne L. (ed.) Liber pontificalis. Texte, introduction et commentaire, vol. 1. Paris, De Boccard Publ., 1955 (in Latin and French).

19. Egidi P. Notizie storiche dell'abbazia durante il Medioevo. I monasteri di Subiaco, 2 vols. Roma, Ministero della Pubblica Istruzione Publ., 1904, vol. 1, pp. 45-184 (in Italian).

20. Frugoni C. Francesco e l'invenzione delle stimmate. Una storia per immagine e parole fino a Giotto e Bonaventura. Torino, Giulio Einaudi Publ., 1993. 431 p. (in Italian).

21. Frugoni C. Quale Francesco? Il messaggio nascosto negli affreschi della Basilica superiore ad Assisi. Torino, Giulio Einaudi Publ., 2015. 608 p. (in Italian).

22. Frugoni A. Subiaco francescana. Bullettino dell'Istituto storico italiano per il Medio Evo e Archivio muratoriano, 1953, no. 65, pp. 107-119 (in Italian).

23. Giovannoni G. Larchitettura dei monasteri sublacensi. I monasteri di Subiaco, 2 vols. Roma, Ministero della Pubblica Istruzione Publ., 1904, vol. 1, pp. 263-402 (in Italian).

24. Huber M. Die Vita illustrata Sancti Benedicti in Handschriften und Kupferstichen. Studien und Mitteilungen zur Geschichte des Benediktinerordens, 1930, no. 49, pp. 433-440 (in German).

25. Lawrence C. H. The Friars: The Impact of the Mendicant Orders on Medieval Society. London - New York, Longman Publ., 1994. 245 p.

26. Matthiae G. Pittura romana del Medioevo, Secoli VI-X. Roma, Palombi Publ., 1987. 310 p. (in Italian).

27. Matthiae G. Pittura romana del Medioevo, Secoli XI-XIV. Roma, Palombi Publ., 1988. 387 p. (in Italian).

28. Migne J.-P. (ed.) Gregorii Magni vita sancti Benedicti ex libro II Dialogorum. Patrologia Latina, vol. 3. coll. 125-204 (in Latin).

29. Morghen R. I primi monasteri sublacensi. Bullettino dell'Istituto storico italiano, 1927, no. 14, pp. 259268 (in Italian).

30. Pace V. Pittura del Duecento e del Trecento a Roma e nel Lazio. La pittura in Italia, Il Duecento e il Trecento, vol. 2. Milano, Electa Publ., 1986, pp. 423-442 (in Italian).

31. Panarelli F. Le grandi abbazie dell'Italia meridionale nel tardo Medioevo. Il monachesimo italiano nel secolo della grande crisi. Atti del V Convegno di studi storici sull'Italia benedettina Abbazia di Monte Oliveto Maggiore (Siena), 2-5 settembre 1998. Cesena, Centro storico benedettino italiano Publ., 2004, pp. 265-289 (in Italian).

32. Pani Ermini L. Subiaco all'epoca di S. Benedetto. Note di topografia, Benedictina, 1981, no. 28, pp. 69-80 (in Italian).

33. Penco G. Crisi e segni di rinascita monastica nel Trecento. Il monachesimo italiano nel secolo della grande crisi. Atti del V Convegno di studi storici sull'Italia benedettina Abbazia di Monte Oliveto Maggiore (Siena), 2-5 settembre 1998. Cesena, Centro storico benedettino italiano Publ., 2004, pp. 1-21 (in Italian).

34. Penco G. Storia del monachesimo in Italia: dalle origini alla fine del Medioevo. Milano, Jaca book Publ., 1985. 538 p. (in Italian).

35. Righetti Tosti-Croce M. Il Sacro Speco di Subiaco e l'architettura dei Crociati in Terra Santa. Il Medio Oriente e l'Occidente nell'arte del XIII secolo. International Congress of the History of Art, 24, Bologna 10-18 settembre 1979. Bologna, Clueb Publ., 1982, pp. 129-135 (in Italian).

36. Righetti Tosti-Croce M. Larchitettura del Sacro Speco. I monasteri benedettini di Subiaco. Cinisello Balsamo, Pizzi Publ., 1982, pp. 75-94 (in Italian).

37. Romano S. Eclissi di Roma. Pittura murale a Roma e nel Lazio da Bonifacio VIII a Martino V (12951431). Roma, Argos Publ., 1992. 520 p. (in Italian).

38. Salvi G. Documenti sul pittore Consolo. Bollettino d’arte, s. IV, 1960, no. 45, pp. 366-367 (in Italian).

39. Speciale L. Il ciclo benedettino del Lezionario Vat. Lat. 1202 e i suoi modelli. Medioevo: $i$ modelli. Conference proceedings. Parma, 1999. Parma, Electa Publ., 2002, pp. 673-681 (in Italian).

40. Steppe J. K. Saint Benoît dans les arts plastiques. Saint Benoît père de l'Occident. Antwerpen, Fonds Mercator Publ., 1980, pp. 53-144 (in French).

41. Tanton K. Inscribing Spiritual Authority: The Temptation of St. Benedict Capital in the Narthex at Vézelay. Viator, 2013, no. 44, 3, pp. 125-155.

42. Verdier Ph. La vie et les miracles de saint Benoît dans les sculptures de Saint-Benoît-sur-Loire. Mélanges de l'Ecole française de Rome. Moyen-Age, Temps modernes, 1977, no. 89, 1, pp. 117-187 (in French). 


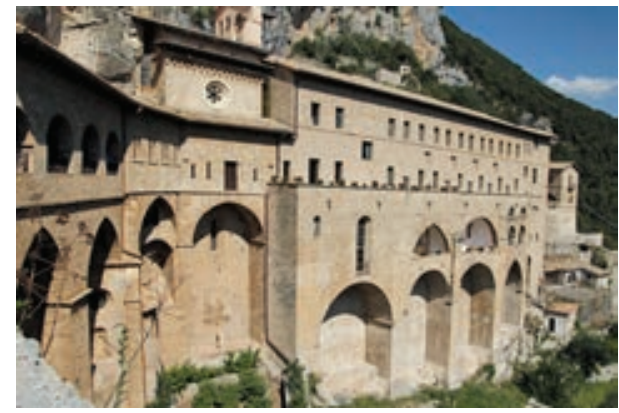

Ill. 101. Sacro Speco. Subiaco, Italy

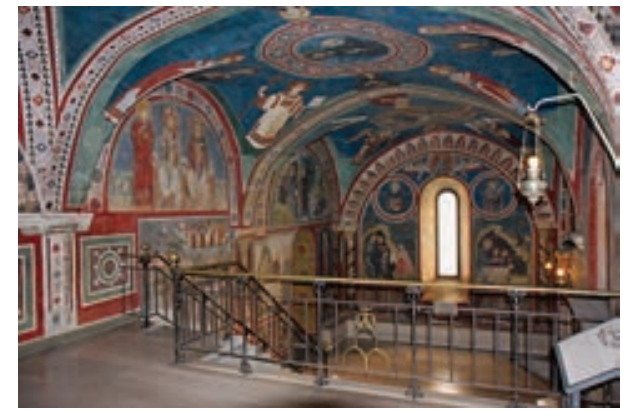

Ill. 103. Lower church from the "landing of the Bulla". Sacro Speco. Subiaco

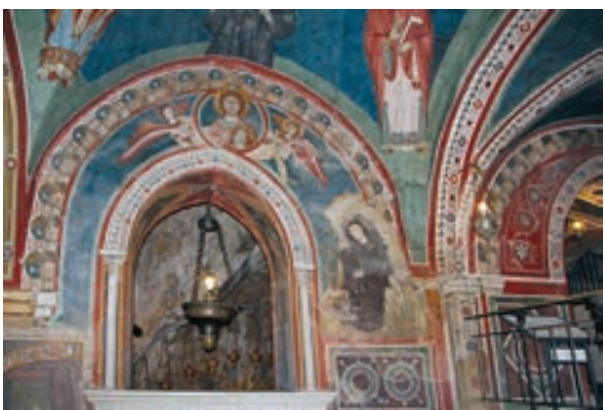

Ill. 105. Benedict showing his cave.

Sacro Speco, lower church, second bay. Subiaco.

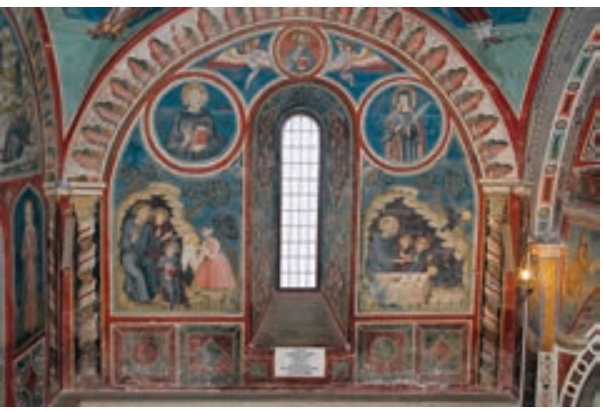

Ill. 107. Miracle of the bread.

Sacro Speco, lower church, third bay. Subiaco

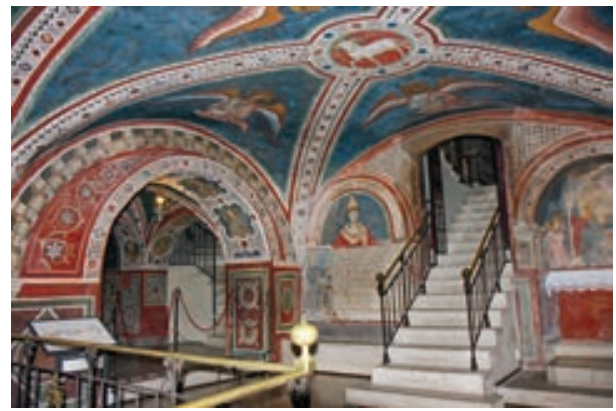

Ill. 102. The so called "landing of the Bulla".

Sacro Speco, lower church. Subiaco

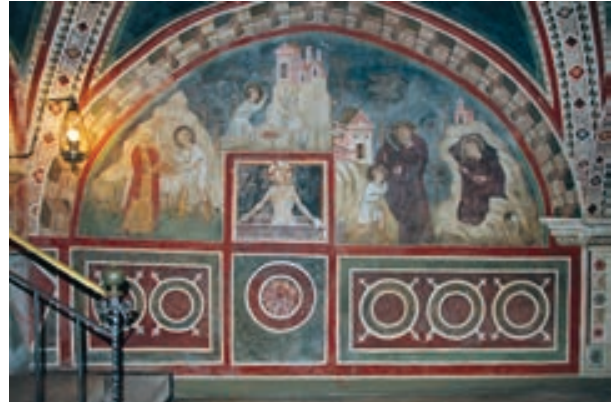

Ill. 104. Miracle of the sieve and Dressing of Benedict.

Sacro Speco, lower church, first bay. Subiaco

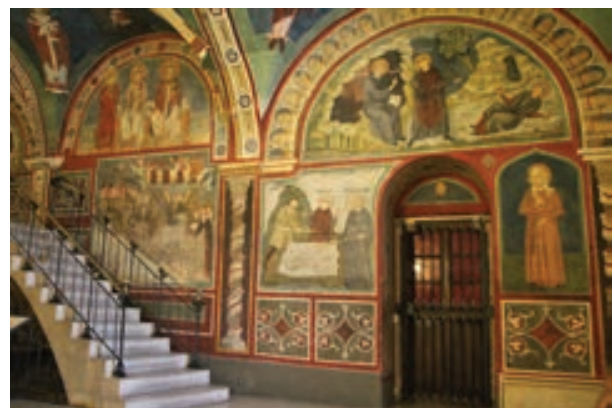

Ill. 106. Sacro Speco, lower church, second and third bays. Subiaco

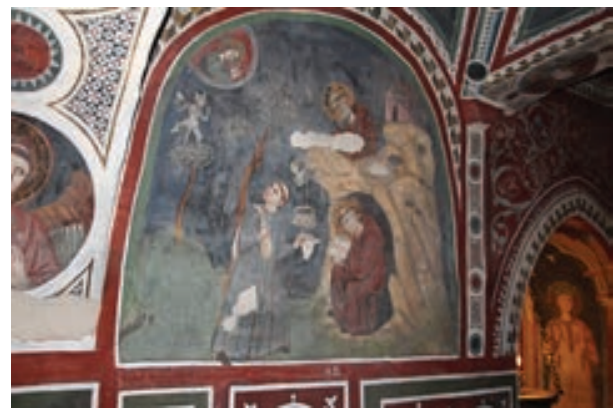

Ill. 108. Miracle of the priest at Easter and Benedict in the cave with monk Romanus. Sacro Speco, lower church, cave of Benedict. Subiaco 